\title{
Viva o Comunismo X Viva Cristo Rei: um estudo de recepção do anticomunismo católico a partir de fontes orais ${ }^{1}$
}

\author{
Carla Simone Rodeghero*
}

\begin{abstract}
Resumo: O presente artigo analisa depoimentos de um pequeno grupo de padres gaúchos a respeito do anticomunismo católico. Procura explicar um denominador comum presente nas lembranças dos entrevistados: a relação direta entre comunismo e perseguição à Igreja no México e na Espanha, com especial referência ao caso do martírio do Padre Miguel Pró, no México, visto como um herói anticomunista.
\end{abstract}

Abstract: The current article analyzes statements by a small group of Roman Catholic priests from Rio Grande do Sul about catholic anti-communism. It intends to explain a common denominator among the memories of the group: the direct relationship between communism and persecution to the Church in Mexico and Spain, with special reference to the martyrdom of Father Miguel Pró in Mexico, seen as an anticommunist hero.

Palavras-chave: Memória. Anticomunismo. Perseguição à Igreja no México e na Espanha.

Key words: Memory. Anti-communism. Persecution to the Church in Mexico and Spain.

O anticomunismo foi um importante componente da política brasileira ao longo do século XX. Ele pode ser caracterizado como uma postura de oposição sistemática ao comunismo e àquilo que é a ele identificado, uma oposição que se adapta a diferentes realidades e se manifesta por meio de representações e práticas diversas (produção de propaganda, ação policial e educacional, pregações religiosas, organização de grupos de ativistas, manifestações

1 Este texto é a adaptação de um dos capítulos da tese Memórias e Avaliações: norteamericanos, católicos e a recepção do anticomunismo brasileiro (1945-1964), defendida no Programa de Pós-Graduação em História da UFRGS, em 2002, sob orientação de Sandra Jatahy Pesavento, com co-orientação de Bárbara Weinstein (University of Maryland).

Professora no Departamento de História da Universidade Federal do Rio Grande do Sul.

Estudos Ibero-Americanos. PUCRS, v. XXXII, n. 1, p. 157-173, junho 2006 
de massa, atuação no campo editorial, na imprensa, no legislativo, etc.). No Brasil, foi produzido e utilizado por um vasto conjunto de instituições, entre as quais tem lugar de destaque a Igreja Católica.

Há vários anos tenho estudado esse tema. Na dissertação de mestrado, publicada com o título $O$ diabo é vermelho: imaginário anticomunista e Igreja Católica no Rio Grande do Sul,2 estudei as formas assumidas pelo anticomunismo católico no Rio Grande do Sul, entre 1945 e 1964. Busquei reconstituir o conteúdo e as imagens que serviam para definir o comunismo e para combatê-lo, rastreei a atuação da Igreja nesse campo e, tendo presente que ela não lutava sozinha, destaquei a especificidade desse anticomunismo frente a um leque mais amplo de grupos e instituições que também se empenharam no mesmo combate. No doutorado, estive preocupada em encontrar indícios da recepção do discurso anticomunista, ou seja, em buscar canais de acesso a pessoas que fizeram parte de grupos visados ou atingidos por campanhas anticomunistas específicas e em desvendar suas "leituras" sobre isso. Nesse intento, realizei um extenso trabalho de história oral com católicos (leigos e membros do clero) que vivem no Rio Grande do Sul, buscando as lembranças, vivências e interpretações a respeito do anticomunismo católico.

É disso que o presente texto trata. Mais especificamente, ele trabalhará com lembranças trazidas à tona nas entrevistas de alguns padres, nas quais destacou-se um denominador comum: a construção de uma relação direta entre comunismo e perseguição à Igreja no México e na Espanha. E esta construção teria tido como base a leitura de um livro que relatava a história da vida e do martírio do padre Miguel Pró, no México. Daí colocou-se o desafio de entender por que este mártir apareceu várias vezes nas entrevistas e de confrontar as lembranças sobre o livro mencionado com o próprio livro. Fez-se necessário explicar por que estes padres viram em Pró um mártir anticomunista, quando o próprio livro não trazia esta abordagem e assim, reconstruir tanto uma leitura sobre o fenômeno em questão, quanto as condições de sua possibilidade. Neste esforço, vou apresentar aproximações entre as fontes orais e outras fontes, bem como as estratégias que permitiram transformar em discurso histórico, parte do material produzido a partir das fontes orais.

2 RODEGHERO, Carla Simone. O diabo é vermelho: imaginário anticomunista e Igreja Católica no Rio Grande do Sul. 2ª ed. Passo Fundo: Editora da UPF, 2003. 
Os cinco padres, cujas entrevistas serão utilizadas aqui - Pe. Firmino Dalcin, ${ }^{3}$ Pe. Guerino Parizzoto, ${ }^{4}$ Pe. Holmes Conzati, ${ }^{5}$ d. Laurindo Guizardi, ${ }^{6}$ e Pe. Nelson Tonello ${ }^{7}$ - apresentaram suas experiências, opiniões e lembranças a respeito da presença da pregação anticomunista e do medo do comunismo em suas famílias, comunidades e nos anos em que estudaram no seminário católico. Pode-se dizer que eles pertencem a três gerações diferentes: a primeira freqüentou o seminário entre os anos 1930 e 1940, a segunda na década de 1950 e a terceira, nos anos 1960. Apesar de três deles atuarem na região da Campanha rio-grandense (nos municípios de Bagé e Alegrete) e outros dois em Passo Fundo, no norte do estado, todos são descendentes de imigrantes europeus, filhos de pequenos agricultores e nascidos em municípios localizados na Serra ou Norte do Estado, na região das velhas e novas colônias italianas (Carlos Barbosa, Nova Bassano, Bento Gonçalves, Tapejara, Getúlio Vargas).

D. Laurindo conta que ainda antes de ingressar no seminário em 1945, ouvia algumas coisas confusas que estavam relacionadas à perseguição no México:

É, a gente ouvia algo confuso, antes de entrar no Seminário. Note que eu entrei no Seminário com dez anos. [...]. Aquilo que eu ouvia falar era relacionado com a perseguição no México, que foi em 1936, 37. A esquerda, além de querer a República, perseguia a Igreja, tanto que matou, não sei quanta gente. Lembro, como pequeno detalhe, que a mãe contava essas coisas pra nós, que ela ouvia, provavelmente na igreja e recordava que no México havia gente que morria dizendo, "Viva Cristo Rei!", e que depois na Espanha, os comunistas... Então, comunista era bicho-papão, era

3 Nascido em Carlos Barbosa, em 1922. Seu ingresso no Seminário de São Leopoldo se deu no ano de 1935. Ele foi entrevistado em duas ocasiões: 15 de dezembro de 1999 e 8 de junho de 2000, em Bagé, por Carla Simone Rodeghero.

4 Nascido em Tapejara, em 1926, ingressou no Seminário Diocesano de Santa Maria em 1944. Foi entrevistado em 25 de julho de 1997, em Passo Fundo.

5 Nascido em Bento Gonçalves, em 1933. No ano de 1943 ingressou no Seminário de Cerro Largo. Foi entrevistado por mim em 15 de junho de 2000, em Alegrete.

6 Sacerdote carlista, hoje bispo de Bagé, nascido em Nova Bassano em 1935. Foi entrevistado por mim em 16 de dezembro de 1999, em Bagé.

7 Sacerdote da diocese de Passo Fundo e professor do Instituto de Teologia e Pastoral de Passo Fundo. Nasceu em 1940, no município de Getúlio Vargas, tendo entrado no Seminário Diocesano de Passo Fundo em 1953. Foi entrevistado em 13 de julho de 1998, em Passo Fundo. A entrevista foi complementada por uma carta: Carta de padre Nelson Tonello a Carla Simone Rodeghero, em 28 de outubro de 2000. 
bicho-papão. Então, as primeiras noções a gente teve de criança. Alguma coisa nebulosa. ${ }^{8}$

Pe. Firmino não recorda de, antes de entrar para o Seminário de São Leopoldo, com treze anos, ter ouvido comentários a respeito do comunismo. A partir daí, passou a ouvir falar da Revolução Mexicana e um nome que ficou na sua memória foi o do Pe. Pró: "O padre Pró. Era célebre a história do padre Pró, ele foi martirizado por ser anticomunista. Depois, mais a Revolução da Espanha. Tudo isso nos vinha, assim, com muita informação". 9 Numa segunda entrevista, Pe. Firmino contou que "havíamos lido também, no refeitório, o livro do Pe. Pró, um padre que no México foi perseguido e martirizado pelos comunistas". ${ }^{10}$

A referência ao mesmo padre Pró apareceu no relato de Pe. Nelson. Ele também contou que a história do Pe. Pró era lida para os seminaristas durante as refeições, no Seminário de Santa Maria. Além desta referência, Pe. Nelson fez chegar até minhas mãos um exemplar do livro Despistou mil secretas. O livro, segundo ele, era lido com muita emoção e entusiasmo no Seminário, "pois o considerávamos modelo para nossos ideais, isto é, todos queriam ser como ele e nos dava muita coragem. Na biblioteca havia filas de espera para poder ler individualmente o livro". ${ }^{11}$

A Espanha, e não o México nesse caso, é importante componente nas lembranças sobre o comunismo presentes na entrevista de Pe. Guerino:

E quando veio a ditadura de 1937, então, dois irmãos meus, eu não tinha idade, vieram aqui [em Passo Fundo] jurar a bandeira e a nova Constituição do Getúlio Vargas, em 1937, e compraram duas revistas: [...] e o que mais me chamou a atenção, que sempre me vem à lembrança, até das imagens, que depois sonhei várias vezes, era de uma professora com vinte alunos, duma escola. Então eles eram católicos e então chegaram lá a milícia, né do comunismo, ela queria que eles gritassem "Viva a República" ou "Viva o comunismo", uma coisa assim, e eles gritavam "Viva Cristo Rei". Pra poupar bala, então enfileiraram na parede, assim. E a professora na frente. Mataram todos. Fuzilaram todos. Nunca esqueço isso. Isso na Espanha. 37. Todos assim, um ao lado do outro.

8 Nas citações de trechos de entrevistas, apresentadas de agora em diante, devem ser consideradas as referências feitas em notas anteriores. Somente serão mencionadas exceções, como no caso de duas entrevistas com a mesma pessoa.

Primeira entrevista com Pe. Firmino Dalcin.

10 Segunda entrevista com Pe. Firmino Dalcin.

11 Carta de padre Nelson Tonello a Carla Simone Rodeghero, em 28 de outubro de 2000. 
Na entrevista com Pe. Holmes, realizada depois das demais, eu mesma questionei sobre o que se falava na Igreja a respeito da guerra na Espanha, o que depois fez com que o diálogo se voltasse para o caso do México e para a figura do Pe. Pró. Já tínhamos discutido a presença do anticomunismo no processo educacional dos seminaristas:

C - O senhor lembra se chegavam a falar a respeito da guerra que aconteceu na Espanha em 1936?

H - Ah, aquilo foi... É engraçado, no refeitório foi lido, como é que é, Espanha em sangue, parece que era, a história. Aquilo foi um episódio, porque foi antes, foi $36,37 \ldots$

C - E, foi antes da Segunda Guerra.

H - Antes da Segunda Guerra. Então, a gente pouco sabia aqui no Brasil, mas nós lemos vários livros sobre o Franco. Franco foi o grande herói que venceu os comunistas. Então, vários livros foram lidos sobre isso aqui, mas isso depois. Não teve tanta repercussão... H - Depois, também o governo do México onde tinha o Pe. Pró. Ele também era um governo maçom, assim, perseguia muito a Igreja Católica. Então, a vida do Pe. Pró era muito... todos nós... Foram lidos vários livros, $O$ Espião secreto. Ele é mártir. Não foi beatificado, mas morreu. Despistou mil secretas era o título de um livro. Então, assim, ele rezava missa escondido e tudo. Mas era uma revolução mais interna, no México.

Pe. Holmes não diz que Pe. Pró foi mártir dos comunistas. Deixa claro que se tratava de "um governo maçom", e que era "uma revolta interna", mas a lembrança veio associada a Franco como tendo sido o herói que venceu os comunistas na Espanha, e também às práticas de leitura no seminário, especialmente no refeitório. Tanto em relação ao México quanto à Espanha, Pe. Holmes conta que se liam muitos livros. Em outra parte da entrevista, quando pergunto se se falava a respeito da Rússia, ele lembra que "se lia muito os mártires, gente assim que, mártires que morreram por isso ou por aquilo". E que quando esses livros falavam sobre a Rússia, a ênfase recaía no ateísmo.

Na entrevista que fiz com Pe. Nelson, ele lembrou de um frei capuchinho que rezava missas na comunidade onde sua família vivia, que era um grande pregador e que conseguia transmitir a todos os fiéis um grande medo a respeito do comunismo. Lembra de ter sentido este medo quando criança e também o medo em relação aos protestantes. Numa comunidade formada basicamente por descendentes de italianos e católicos, a presença de um ou outro protestante era vista com desconfiança. No caso do seminá- 
rio, lembrou da história do Pe. Pró, lida durante as refeições, e me emprestou o livro Despistou mil secretas, como já foi comentado.

\section{A historia do Pe. Pró e a perseguição à Igreja}

Vê-se que o Pe. Pró foi mencionado por três dos meus interlocutores: Pe. Firmino, Pe. Holmes e Pe. Nelson. Os últimos dois se referiram especificamente ao livro, que passo então a descrever e no qual busco os elementos de anticomunismo que ficaram na memória destes entrevistados.

Despistou mil secretas, escrito por Afonso de Santa Cruz, sacerdote jesuíta, e publicado pela primeira vez em $1954,{ }^{12}$ conta a história de Miguel Agostinho Pró Juarez, o padre Pró, nascido no México, em 1891, e fuzilado em 1927. Vários capítulos são destinados a mostrar a infância e juventude do protagonista. Neles é possível perceber que o autor está buscando mostrar indícios da fé, do heroísmo e da firmeza de caráter que o referido padre iria demonstrar mais tarde, ao morrer, como mártir em defesa do catolicismo. Os degraus percorridos por Pró para chegar a este fim podem ser assim sumarizados:

- quando criança, numa família muito religiosa, é salvo de uma doença que quase o conduz à morte, com a intercessão de Nossa Senhora de Guadalupe;

- é educado em casa por uma professora particular, pois os pais não querem colocá-lo em colégio público, onde "reina o ateísmo";

- é mandado, por engano, a uma escola protestante, e retirado de lá tão logo isso é descoberto;

- se enamora de uma moça e, por causa disso, se afasta temporariamente dos conselhos da mãe e da Igreja;

- cai em si, durante um período de Missões, e decide que será jesuíta;

- faz seus estudos no México e depois na Europa (Espanha, Bélgica), onde procura se aproximar dos operários, especialmente mineiros, e onde confronta socialistas em suas discussões;

- se submete a delicadas operações cirúrgicas devido a um problema no estômago, que suporta com resignação;

- volta ao México, num período em que a religião católica é proibida. Nesse momento, usando uma série de subterfúgios, con-

12 O exemplar que estou utilizando faz parte da $4^{a}$ edição - de 40 mil cópias - publicada em 1961, pela Casa Editora da Pia Sociedade Filhas de Maria, em Porto Alegre. 
segue despistar a polícia secreta e levar auxílio espiritual para os fiéis (confissão, distribuição de comunhão, realização de batizados e casamentos, pregação de retiros, ensino da catequese para crianças, etc.);

- depois de um bom tempo despistando a polícia, é preso, fuzilado e enterrado como herói e mártir da fé;

- seu enterro é acompanhado por milhares de pessoas que o conduzem ao túmulo dando vivas a Cristo Rei.

O tema do comunismo, ou do anticomunismo, aparece em apenas quatro momentos do livro. Fala-se em comunismo (ou socialismo) nas situações que seguem. Quando o Pe. Pró está na Bélgica, encontra-se com socialistas, que, num parágrafo seguinte do relato, já são nomeados como comunistas. Os socialistas/comunistas são representados como pessoas atrevidas, que se dão o direito de questionar o padre. Este, com uma boa dose de ironia, vence as discussões e revela as incoerências dos oponentes. ${ }^{13}$ Numa outra situação, relata-se que o Pe. Pró, tendo voltado ao México, prega, às escondidas, um retiro para oitenta professoras estaduais e que "muitas delas andam imbuídas de idéias socialistas e atéias...”.14 Na mesma época, num clima de perseguição à Igreja, quando ele mesmo estava sendo caçado, Pe. Pró, disfarçado de médico, tem uma conversa com dois policiais e se faz passar por anticlerical. Conta que estudou na Espanha e se refere ao comunismo naquele país: "estive uns anos na Espanha. Lá o comunismo é prometedor, camaradas". ${ }^{15}$ Finalmente, quando o livro relata as tratativas para o fuzilamento do Pe. Pró, de dois irmãos seus e de outros líderes católicos, o narrador conta que "muitos comunistas e amigos de Calles recebem secretamente o convite de assistirem ao fuzilamento dos irmãos Pró". 16

Antes de analisar a leitura dos padres sobre o comunismo, a perseguição à Igreja e o martírio do padre Pró, serão apresentadas algumas informações a respeito dele. Conforme explica Jean Meyer, ${ }^{17}$ o padre Pró foi um padre jesuíta executado pelo governo mexicano de Calles, em 1927. Morreu declarando Viva Cristo Rei, a mesma palavra de ordem adotada pelo movimento Cristero que sustentou uma guerrilha contra o Estado entre 1926 e 1929, e que, entre outras coisas, lutava para defender a fé católica. Na época, o

13 SANTA CRUZ, Afonso de. Despistou mil secretas. Porto Alegre: Casa Editora da Pia Sociedade Filhas de Maria, 1961, p. 73.

14 Ibidem, p. 87.

15 Ibidem, p. 91.

16 Ibidem, p. 130

17 MEYER, Jean. La Cristiada. Cidade do México: Siglo Veintiuno, 1973 (3 volumes). 
presidente Calles colocou em prática - e exigiu que os estados também o fizessem - os artigos que restringiam a atuação e o poder da Igreja e que já estavam inscritos na Constituição de 1917. O Artigo 3 estabelecia o ensino leigo em escolas públicas e privadas, além de impedir que religiosos dirigissem escolas; o Artigo 5 proibia a existência tanto de comunidades quanto de votos religiosos; o 27 regulava o direito de propriedade, atingindo de diversas maneiras as propriedades da Igreja e o direito dela reger as mesmas; e o artigo 130 rezava que as Igrejas eram entidades sem personalidade jurídica. Isso abria espaço para o Estado intervir em questões de culto e disciplina, no número permitido de ministros do culto em cada localidade, na restrição dos direitos políticos e de expressão dos religiosos. ${ }^{18}$

Os bispos mexicanos foram instruídos pelo Vaticano a se acomodar à situação, ter paciência e respeitar o poder constituído. Entre os bispos, no entanto, havia divergências, e muitos deles não seguiram essa linha proposta pelo papa Pio XI, a tal ponto que em 1926, depois de violentas investidas do governo contra igrejas, conventos, autoridade do clero, etc., os bispos decidiram pela suspensão do culto. ${ }^{19}$ Conforme se lê em Despistou mil secretas, o padre Pró retorna ao México nesse contexto.

Tal decisão foi recebida pela população com desespero e gerou um intenso surto de piedade. Camponeses de diversas regiões do país se sentiram compelidos a pegar em armas para garantir a continuidade dos ritos religiosos. Meyer destaca a importância que os rituais, os sacramentos e os padres tinham para esses camponeses: "um cristianismo dos sacramentos e da Eucaristia, no qual a suspensão do culto, a desaparição do sacerdote, que pode viver a vários dias de distância, porém ao qual se ia, se traduzem em morte espiritual, da qual se escapa através da insurreição". ${ }^{20}$ A defesa de tudo isso, justificaria a luta e o martírio.

O clero desautorizou os rebeldes. Da mesma forma que Roma, os bispos e padres pediam paciência e obediência e ofereciam o martírio como a saída. Os camponeses também tinham o martírio como horizonte, mas um martírio relacionado à luta. A possibilidade de morrer para ganhar o céu lhes dava coragem e inspira-

18 De acordo com SOLIS, José M. Romero de. Iglesia y revolución en México (19101940). In: FLICHE, Augustin; MARTIN, Victor. Historia de la Iglesia: Guerra Mundial y Estados Totalitários. Valência: Edicep, 1980, v. 26, p. 470; e BERBUSSE, Edward J. The unofficial intervention of United States in Mexico's religious crisis (1926-1930). The Americas, v. 23, n. 1, July 1966.

19 MEYER, op. cit., v. 2, p. 382 e 383.

$20 \quad$ Ibidem, v. 3 , p. 309. 
ção. ${ }^{21}$ Meyer, em seu estudo sobre o movimento Cristero, fez entrevistas com sobreviventes e contou 250 mártires entre os rebeldes, seguindo um critério que buscava em cada caso os seguintes elementos: resignação, dificuldades extremas de resistência, atrocidade dos sofrimentos, magnitude da tentação, desejo do céu. ${ }^{22}$

As Leis de Calles seriam colocadas em prática em 31 de julho de 1926. Alguns dias antes, como já foi comentado, o episcopado suspendeu os serviços religiosos e a Liga Nacional Defensora da Liberdade Religiosa, uma organização leiga fundada em 1925, patrocinou um boicote econômico. A estratégia de resistência passiva foi ultrapassada pelos levantes rurais. No final de 1926, a Liga passou a coordenar grupos locais em armas. A insurreição durou três anos, reuniu um contingente de cerca de 25 mil combatentes e se tornou conhecida como movimento Cristero, devido à palavra de ordem dos rebeldes: "Viva Cristo Rei". Em agosto de 1929, o embaixador norte-americano Dwight Morrow negociou um acordo entre o episcopado e o governo, ocasião em que os rebeldes depuseram armas. ${ }^{23}$

Não há nenhum indício de que o Pe. Pró tenha participado desse movimento rebelde. Ele pode ter tido alguma relação com a Liga. Mas, a morte dele se deu em meio ao clima de extrema tensão entre Estado e Igreja. Tendo presente este contexto, fica claro que não se tratava de uma luta entre comunismo e Igreja Católica, mas, muito mais, um capítulo dos conflitos entre essa e os Estados liberais, na forma como elas se desdobraram no México, no período da Revolução chamado de constitucionalista.

Em Despistou mil secretas, os acontecimentos de 1926 são assim narrados:

afixam-se nas portas dos templos os decretos de proibição do culto religioso e os párocos, com os corações alanceados de dor, esvaziam céleres os tabernáculos. [...]. A Igreja do México desce para as catacumbas. Calles, o Nero do século XX, extravasa ódio satânico contra Cristo. Os sacerdotes são declarados nocivos ao Estado. ${ }^{24}$

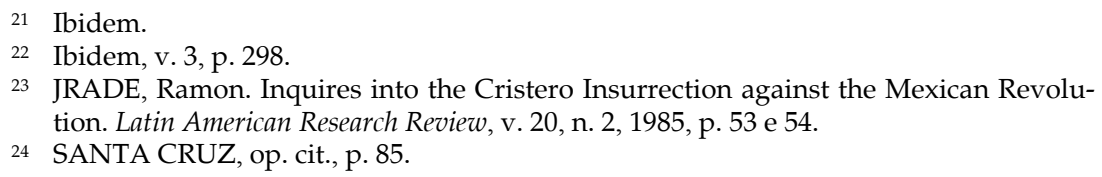




\section{México e Espanha no discurso católico anticomunista}

Pelo que se viu, não foram os comunistas - nem um Estado comunista - os responsáveis pelo fuzilamento do padre. Nem era a questão do comunismo a principal preocupação do livro Despistou mil secretas, mesmo que ela estivesse presente nele. $\mathrm{O}$ livro não defende a idéia de que o Pe. Pró foi mártir do comunismo. Apesar disso, a história desse padre pôde ser lida como a de um herói anticomunista em algumas das entrevistas e, em outras, ela veio à tona quando se falava sobre comunismo. Por quê?

Em primeiro lugar, é importante ter presente que o caso do padre Pró se tornou internacionalmente conhecido, pois a sua execução se deu frente a câmeras da imprensa, de tal forma que a imagem do governo mexicano ficou comprometida. A foto do padre Pró, de braços abertos e com olhar sereno esperando o fuzilamento, correu o mundo. Meyer diz que antes de Pró, muitos outros - em torno de 90 - sacerdotes tiveram o mesmo fim, mas que a Igreja não fizera as mesmas denúncias que foram feitas no caso daquele. ${ }^{25}$

Mas, talvez o mais importante seja mostrar que a construção que aproximava a perseguição à Igreja no México ao comunismo fazia sentido dentro de uma lógica presente em várias encíclicas que condenavam o liberalismo, e o ligavam ao socialismo e ao comunismo. Segundo Robert H. Vinca, "a perseguição à Igreja Católica pelo governo mexicano era fundamentalmente orientada pela influência do liberalismo doutrinário da Europa do século XIX, adaptado à cena mexicana”. ${ }^{26}$

O mesmo autor - que escreve tomando a posição da Igreja situa o socialismo como resultado lógico da Constituição de 1917, escrita por teóricos seculares. Os desdobramentos na linha do socialismo teriam sido um decreto de 1926 proibindo toda escola de possuir qualquer emblema religioso e a tentativa, durante os anos 1930, de introduzir a educação sexual no currículo. Em 1934, numa emenda à Constituição, sob o governo Cárdenas, ainda segundo Vinca, foi estipulado que a educação promovida pelo Estado deve-

25 MEYER, op. cit., p. 298 (v. 3).

26 VINCA, Robert H. The American Catholic Reaction to the Persecution of the Church in Mexico, from 1926 to 1936. In: KANTOWICZ, Edward. Modern American Catholicism (1900-1965): Selected Historical Essays. New York/London: Garland Publishing, 1988, p. 287. O texto foi originalmente publicado em Records of the American Catholic Historical Society of Philadelphia, n. 79, 1968, p. 3-38. A tradução é minha. 
ria ser socialista, excluindo toda doutrina religiosa, combatendo o fanatismo e o preconceito. ${ }^{27}$

Se a condenação do liberalismo já era a tônica de documentos como o Silabus, de Pio IX, escrito no contexto do Vaticano I, de 1870, ela continuou se manifestando em outros documentos como a Rerum Novarum, de 1891, e a Quadragesimo Anno, de 1931. Em todas essas encíclicas, o liberalismo era condenado pelos seus tons materialistas, pelo primado da razão sobre a fé, pela destruição de valores morais, pelo desprezo à autoridade constituída, pelo não respeito aos direitos da Igreja. O liberalismo prepararia o caminho para algo pior que ele, o socialismo e o comunismo. Os artigos da Constituição mexicana de 1917 eram vistos, então, como indícios de que os mesmos "preconceitos" em relação à Igreja, que já eram combatidos por ela no século XIX, iriam ser a base da sociedade mexicana, com tão fundas raízes católicas.

Assim, já havia uma tradição anterior relacionando liberalismo a comunismo. Mas, depois disso, especialmente entre 1926 e 1929, a situação para a Igreja no México ficou difícil, gerando mobilizações no exterior, tanto na Europa quanto nos Estados Unidos. No último caso, os católicos se envolveram numa série de atividades de assistência a mexicanos exilados e também de pressão no Congresso e no Executivo para que as autoridades condicionassem reconhecimento e apoio ao governo mexicano à resolução dos problemas entre Estado e Igreja, conforme se vê no já citado trabalho de Vinca.

A perseguição ao clero e aos fiéis católicos no México foi intensamente combatida pelo papa Pio XI, que, em vários momentos, se referiu à mesma. ${ }^{28}$ No final dos anos 1930, depois de serenadas as tensões maiores, o México tornou-se para a Igreja Católica um símbolo da perseguição e passou a figurar em encíclicas que se referiam ao problema do comunismo, como é o caso da Divini Redemptori, que Pio XI escreveu em 1937, no contexto da Guerra Civil Espanha, tratando especificamente do "comunismo ateu".

Essa encíclica trata dos casos de perseguição à Igreja, entendendo-os como uma das funestas conseqüências da aplicação da doutrina comunista, a qual seria difundida por meio de propaganda bem organizada e sedutora, e teria seu caminho preparado pelo

27 Ibidem, p. 309

28 As encíclicas que Pio XI dirigiu ao México foram: Paterna sane, em 1926; Iniquis afflictisque, também em 1926; Acerba animi, em 1932; e Firmissimam constantian, em 1937. 
liberalismo. Como se vê no trecho abaixo, o nome do México aparece ao lado daquele da Rússia:

Onde quer que os comunistas conseguiram radicar-se e dominar - e aqui pensamos com particular afeto paterno nos povos da Rússia e do México - aí, como eles próprios abertamente o proclamam, por todos os meios se esforçaram por destruir radicalmente os fundamentos da religião e da civilização cristãs, e extinguir completamente a sua memória no coração dos homens, especialmente da juventude. Bispos e sacerdotes foram desterrados, condenados a trabalhos forçados, fuzilados ou trucidados de modo desumano; simples leigos tornados suspeitos por terem defendido a religião, foram vexados, tratados como inimigos, e arrastados aos tribunais e às prisões. ${ }^{29}$

Pio XI também se refere à Espanha:

Não é esta ou aquela igreja destruída, este ou aquele convento arruinado; mas, onde quer que lhes foi possível, todos os templos, todos os claustros religiosos, e ainda quaisquer vestígios da religião cristã. [...]. E não se limitou o furor comunista a trucidar bispos e muitos milhares de sacerdotes, religiosos e religiosas..., mas fez um número muito maior de vítimas em leigos de todas as classes. ${ }^{30}$

A referência ao México e à Espanha não constava apenas de encíclicas. É possível vê-la em outras fontes católicas, na segunda metade da década de 1930, época em que a ameaça do comunismo tomou dimensões maiores no Brasil, com os fatos que ficaram conhecidos como Intentona Comunista. O Boletim Unitas, órgão oficial de divulgação da arquidiocese de Porto Alegre, por exemplo, reproduziu nos anos de 1936, 1937 e 1938 pronunciamentos do arcebispo D. João Becker que faziam conexões entre comunismo, México e Espanha, e se concentravam no tema da perseguição do Estado à Igreja. ${ }^{31}$

Na avaliação de D. João, a atualidade - anos 1936, 37, 38 - tinha como marca a crise moral das sociedades modernas. ${ }^{32}$ Essas sociedades - e entre elas estava o Brasil - estariam sendo abaladas em suas bases: na família, na propriedade, na dignidade humana e na legítima autoridade. Tal crise era vista como estando em contí-

29 PIO XI. Divini Redemptoris. São Paulo: Paulinas, 1965, p. 16, parágrafo 20.

30 Ibidem.

31 É o que se pode ver nos seguintes números do boletim Unitas: n. 9, 10, set.-out. 1936, ano 23, p. 261 e p. 433; n. 7, 8, jul.-ago., 1937, ano 24, p. 206; e n. 1, 2, 3, jan.-fev.-mar., 1938 , ano 25 , p. 60.

32 O tema da crise moral estava presente com freqüência nos pronunciamentos de D. João Becker. Ver: ISAIA, Artur César. Catolicismo e autoritarismo no Rio Grande do Sul. Porto Alegre: EDIPUCRS, 1998. 
nua expansão, de tal forma que o resultado dela estaria fazendo com que até os povos cristãos - como os espanhóis e os mexicanos - fossem atingidos pelo comunismo russo.

Parece que esta avaliação demarca dois momentos particulares do avanço do comunismo: o primeiro, no qual se desencadeia uma crise moral em que os valores da família, da propriedade, da religião e da autoridade são questionados; e o segundo, quando se dá a instalação completa de um regime marcado pela violação dos símbolos católicos, pelo assassinato de padres, pela pregação do ateísmo por parte dos poderes públicos. O Brasil estaria vivendo a primeira fase. O México e a Espanha, a segunda. Evitar a chegada desta segunda fase seria uma das tarefas primordiais da Igreja Católica. Segundo o arcebispo de Porto Alegre, somente a Igreja poderia restaurar, entre as nações, o reino de Cristo. Daí a importância de leis que fossem simpáticas à instituição nas Constituições dos países.

Vê-se, então, que o México e Espanha ganharam lugar central nos argumentos católicos contra o comunismo, durante a década de 1930. A segunda metade da década foi marcada pela Guerra Civil Espanhola. Na Espanha, a queima de igrejas foi intensa durante os anos da guerra. Segundo Hugh Thomas, "150 igrejas foram totalmente destruídas, 4.850 danificadas, das quais 1.850 destruídas pela metade ou mais". $33 \mathrm{O}$ mesmo autor considera que aquele foi um momento de ódio apaixonado à religião e às suas obras. A Igreja representava o conservadorismo, e durante a guerra - em praticamente toda a Espanha - se aliou com as forças nacionalistas. Quando as tropas de Franco alcançaram seu último objetivo, o papa Pio XI telefonou ao Generalíssimo parabenizandoo "pela vitória da Espanha Católica". 34

No que diz respeito às denúncias feitas pela Igreja a respeito de perseguições, violência, assassinatos, destruição de templos em momentos particulares da história do México e da Espanha, não se pode dizer que elas tenham sido inventadas. Mas, no discurso católico, muitas nuances se perderam e parece que não fazia sentido - ou não era possível - distinguir quais eram os grupos e projetos políticos envolvidos nas lutas, e qual era o lugar do comunismo nisso tudo.

Para a elucidação da leitura que os entrevistados fizeram sobre a história do padre Pró, é preciso também refletir sobre o lugar

33 THOMAS, Hugh. A Guerra Civil Espanhola. Rio de Janeiro: Civilização Brasileira, 1964, v. 2, p. 339.

34 Ibidem, p. 335. 
do martírio no imaginário católico, e no caso específico do México. Numa situação de perseguição e clandestinidade como a vivida pelos católicos mexicanos, o martírio se colocava como uma possível - e talvez única - saída para alguns. Por outro lado, seria interessante percorrer com mais profundidade o caminho da transformação do Pe. Pró num mártir e descobrir como isso foi acoplado ao discurso anticomunista. Em obra escrita em 1936 pelo jesuíta norte-americano Wilfrid Parson, e intitulada Martírio mexicano, que relata as situações de perseguição à Igreja entre 1926 e 1936, há um capítulo reservado ao padre Pró. ${ }^{35}$ Nele são transcritas cartas que teriam sido escritas pelo padre, as quais têm uma série de pontos em comum com aquilo que se pode ler em Despistou mil secretas. $\mathrm{O}$ mesmo acontece em obra de Robert Royal, publicada em 2001, nos Estados Unidos, sob o ponto de vista católico, e que trata dos mártires católicos do século XX. ${ }^{36} \mathrm{O}$ primeiro capítulo é reservado ao padre Pró. Não há no relato referências a comunismo no México, apenas a socialismo, quando o autor classifica de socialista a Constituição de 1917, que seria a primeira constituição socialista do mundo, anterior mesmo à soviética. ${ }^{37}$ Há um comentário sobre a capacidade que Pró tinha, enquanto estava na Bélgica e mantinha relações com a Juventude Operária Católica (JOC), de reconhecer o zelo admirável cultivado por comunistas e socialistas, apesar dos erros que via nos dois sistemas". ${ }^{38}$ A questão do martírio apareceu também nos relatos dos padres entrevistados, que lembram de ter lido ou ouvido histórias sobre isso nos anos de estudo no seminário.

35 PARSONS, Wilfrid, S.J. Fater Pro. In: Mexican Martyrdom. New York: The Macmillan Company, 1936, p. 41 a 53.

36 ROYAL, Robert. Miguel Pro and the Mexican Tragedy. In: The Catholic Martyrs of the Twentieth Century: a comprehensive wold history. New York: Crossroad Publishing Company, 2001, p. 15 a 42.

37 Ibidem, p. 15.

38 Ibidem, p. 28. O mesmo autor dedica um capítulo, o quinto, à Espanha. Em Spanish Holocaust. Royal relata as violências contra os católicos, levadas a efeito na Espanha durante o governo republicano e a Guerra Civil. Defende a postura da Igreja e sua aproximação aos nacionalistas, além de argumentar que Franco não era fascista. $\mathrm{O}$ autor propõe fazer uma análise não ideológica da Guerra Civil, mas a tônica geral do relato é a crítica aos republicanos. Faz, no entanto, distinções entre grupos de compunham o campo republicano. Admite que o comunismo era apenas um dos múltiplos fatores das perseguições anticlericais e que o movimento anarquista tinha um papel central nelas. Cita também os trotskistas e maçons que desenvolveriam uma campanha usando o tema da Inquisição espanhola (p. 123). Finalmente, Royal faz relações entre a situação do México, da Rússia e da Espanha, concluindo que a perseguição religiosa foi mais intensa no último país. 


\section{Considerações finais: a comunidade dos seminaristas católicos e a recepção do anticomunismo}

Voltando para Pe. Firmino, Pe. Holmes, d. Laurindo, Pe. Guerino e Pe. Nelson: as lembranças deles devem ser situadas dentro de quadros sociais e temporais dos quais fizeram parte também os posicionamento do papa Pio XI, e os de d. João Becker no que se refere ao tema do comunismo e ao lugar que o México e a Espanha ocuparam na memória da instituição. Os cinco entrevistados foram sujeitos parciais do processo de construção, difusão e recepção de um imaginário anticomunista, no qual México e Espanha tinham um lugar reservado.

Nesta análise, os cinco padres entrevistados estão sendo encarados como destinatários e receptores do discurso católico anticomunista. A situação deles enquanto seminaristas os colocava nessa posição. E o próprio livro Despistou mil secretas dá uma série de indícios sobre quem seriam seus leitores-alvo. O exemplar que chegou às minhas mãos faz parte da quarta edição que é de 1961 e conta com 40 mil exemplares. Ele foi impresso com o apoio da arquidiocese de Porto Alegre, bem como da Ordem dos Jesuítas. Conta com 140 páginas e algumas ilustrações. Faz parte da coleção "Em busca de um ideal", que, segundo nota introdutória do Pe. Reinaldo Wenzel, S.J., vem despertando "crescente interesse na Mocidade Brasileira". O autor, Afonso de Santa Cruz, padre jesuíta, na época da publicação, trabalhava com a Juventude Estudantil Católica, em Curitiba.

Se essas palavras permitem concluir que os jovens católicos em geral eram os principais destinatários do livro, também é possível inferir que ele tenha sido especialmente dirigido aos seminaristas. Note-se a forma como a obra trata da vocação para o sacerdócio. Ela descreve os passos seguidos pelo Pe. Pró para descobrir sua vocação sacerdotal, para assumi-la e para honrá-la. Os jovens leitores da obra deveriam ser tocados por esta experiência particular e transferi-la para o seu próprio cotidiano. Note-se também a referência dos meus entrevistados à obra sendo lida no seminário. Além disso, o livro constrói a imagem de um "padre revolucionário", aquele que vive numa situação de perseguição, mas que consegue, assim mesmo, dar conta do seu trabalho de catequizar, confessar, dar a comunhão, pregar, etc. O padre que foi sendo construído dentro de uma família temente a Deus e a Nossa Senhora; uma família na qual a mãe tinha um papel de destaque, sempre zelando pela disciplina e pela fé dos filhos. 
As histórias e trajetórias dos cinco padres mencionados permitem pensá-los como membros de uma mesma "comunidade", 39 caracterizada por uma formação e por práticas e leituras em comum. Durante muitos anos os padres jesuítas estiveram à frente de seminários no Rio Grande do Sul e formaram várias gerações de novos sacerdotes, que possivelmente tiveram acesso a informações e histórias sobre a perseguição à Igreja como um todo e, especificamente, sobre casos como o do Pe. Pró, que também era um jesuíta. Os padres Firmino, Holmes, Guerino e Nelson tiveram em sua formação professores jesuítas, nos seminários de Santa Maria, de São Leopoldo e de Viamão. Desde os anos em que Pe. Firmino ingressou no seminário até aqueles em que o Pe. Nelson fez o mesmo, continuou existindo a prática da leitura durante as refeições. E entre essas leituras estava a da história do Pe. Pró.

Essa "comunidade de imaginação" se tornava mais unida na medida em que via a necessidade de se solidarizar com outros membros - ainda que desconhecidos -, mas que estavam sendo perseguidos, presos e mortos no México, na Espanha, na Rússia e em todos os países onde o comunismo estivesse no poder. Parece ter sido essa a sensação vivida. E isso fica mais evidente na lembrança de padre Nelson sobre a fila de espera na biblioteca para ler o livro do padre Pró, bem como quando ele fala que o padre mexicano era um modelo e que os seminaristas ambicionavam ser como ele. E o martírio pode ter sido visto como o máximo de doação a ser ambicionado.

As entrevistas utilizadas neste artigo e as demais, exploradas em minha tese de doutorado, permitem supor que os seminários católicos gaúchos no período em que foram freqüentados pelos padres entrevistados eram espaços privilegiados em que os alunos podiam - ou deviam - desenvolver o hábito da leitura, onde o tema do comunismo era tratado, às vezes no seio de pregações anticomunistas e, às vezes, como uma questão em disputa, o que se pode depreender de relatos referentes ao Seminário Maior de Viamão, nos anos 1960. Alguns dos entrevistados lembram de pregações anticomunistas e de leituras neste sentido já no Seminário Menor. A maioria deles se refere ao de Santa Maria. Aí eles teriam começado a conhecer que estava em curso uma luta entre Igreja e comunismo, uma das configurações da luta entre o bem e o mal.

39 Aqui estou me inspirando em Benedict Anderson e suas "comunidades imaginadas", utilizadas na explicação do surgimento das nações e nacionalismos a partir do final do séc. XVIII. ANDERSON, Bendict. Imagined Communities: Reflexions Upon the Origin and Spread of Nationalism. London: Verso, 1980. 
No caminho percorrido para explicar as relações que parte dos entrevistados fizeram entre comunismo e perseguição à Igreja Católica, centradas na história do martírio do padre Pró, os passos dados foram o instigamento e a escuta das lembranças e análises deste pequeno grupo de indivíduos, o confronto entre as leituras feitas pela memória e o livro que os protagonistas teriam lido ou ouvido ler, a busca dos leitores almejados pela publicação, o esclarecimento sobre os conflitos entre Estado e Igreja no México, a recuperação da tradição construída nos documentos da Igreja Católica relacionando o comunismo à perseguição à Igreja no México e na Espanha, a menção ao ambiente dos seminários católicos e à comunidade formada pelos seminaristas. Também foi considerada a origem deste conjunto de entrevistados, todos descendentes de imigrantes italianos e alemães, e em sua maioria filhos de famílias de pequenos agricultores.

Procurou-se, assim, mostrar que as memórias desses padres sobre o comunismo e a perseguição à Igreja no México e na Espanha foram construídas dentro de quadros sociais e temporais marcados por preocupações e posicionamentos da hierarquia, pelo sistema de educação nos seminários, pela forma como esse sistema se adequava a questões conjunturais, pela origem étnica e socioeconômica dos entrevistados, pelas lembranças e reflexões sobre lembranças que de alguma forma diziam respeito aos temas comunismo e anticomunismo. Pretendeu-se, assim, construir uma estratégia para um estudo de recepção, a qual buscou, por um lado, descrever como certos fenômenos e processos foram vivenciados por um grupo de indivíduos e, por outro, explicar as razões pelas quais as leituras dos mesmos faziam sentido num determinado contexto. 